Research Article

\title{
Selectivity of post-emergent herbicides for weed control in birdsfoot trefoil crops
}

\author{
Bruno M. Silva ${ }^{a}$, Renan R. Zandonáa*, Roberto C. A. Neto ${ }^{a}$, Jonathan Torchelsen ${ }^{a}$, Dirceu Agostinetto ${ }^{a}$ \\ a Universidade Federal de Pelotas, Pelotas-RS, Brasil.
}

\section{INFORMATION ARTICLE}

Received: January 31, 2019

Accepted: March 17, 2020

\section{Keywords:}

Lotus corniculatus

management

efficiency

*Corresponding author:

<renan_zandona@hotmail.com>

Cite this article:

Silva BM, Agostinetto D, Zandoná, RR, Avilla Neto RC, Torchelsen J. Selectivity of post-emergent herbicides for weed control in birdsfoot trefoil crops. Planta Daninha. 2020;38:e020219317.

https://doi.org/10.1590/S0100-83582020380100055

Conflict of Interest:

The authors declare that there is no conflict of interest regarding the publication of this manuscript.

Copyright: This is an open-access article distributed under the terms of the Creative Commons Attribution License, which permits unrestricted use, distribution, and reproduction in any medium, provided that the original author and source are credited. (a) (1)

\section{HIGHLIGHTS}

- The work was structured with greenhouse and field studies at different stages of crop development.

- In birdsfoot trefoil crops, there are no commercial products registered in Brazil for the management of weeds.

- Some herbicides can be registered for weed control in birdsfoot trefoil crops.

\section{ABSTRACT}

Background: Competition with weeds and the lack of selective herbicides registered for birdsfoot trefoil crops affect their development and limit their productivity.

Objective: This study aimed to evaluate selectivity of post-emergent herbicides for weed control in birdsfoot trefoil crops.

Methods: Experiments were carried out in a greenhouse and on a field, in both vegetative and reproductive development stages of birdsfoot trefoil crops. Treatments were composed of post-emergent herbicides recommended for soybean, corn and garlic cultivation. Phytotoxicity (PHYTO), plant height (HEI), shoot dry matter (SDM) and root dry matter (RDM) were evaluated. Data were submitted to the analysis of variance and when means were significant, they were compared by the Duncan's Test $(p \leq 0.05)$. In order to determine post-emergent herbicides which were selective to the crop, those that provided PHYTO below or equal to $15 \%$ were recommended, since they did not significantly interfere with morphological variables HEI, SDM and RDM, by comparison with the control.

Results: Unlike results found in the vegetative stage, birdsfoot trefoil plants were more tolerant to phytotoxic effects of herbicides imazethapyr, chlorimuron-ethyl, cloransulam-methyl and fomesafen in the reproductive stage. The variables were negatively affected by the herbicides bentazon, glyphosate and carfentrazone-ethyl, with PHYTO higher than $40 \%$ at 20 days after treatment in the vegetative stage.

Conclusions: Herbicides imazethapyr, chlorimuron-ethyl and flumetsulam, when applied as post-emergent ones, regardless of the development stage of the species, are selective to birdsfoot trefoil crops, without affecting crop development, whereas herbicides cloransulammethyl and fomesafen are not selective to them. 


\section{INTRODUCTION}

Birdsfoot trefoil (Lotus corniculatus L.), which is a forage plant that belongs to the Fabaceae family, is known for its rusticity and adaptability to edaphoclimatic variations (Grant and Small, 1996). It is suited to sandy, clayish, poor and moderately fertile soils, but it also exhibits good tolerance to acid, badlydrained, dry and low fertile soils (Ayala and Carámbula, 2009). Even though it is a rustic crop, it has problems in the establishment stage, such as slow plant growth and development (Formoso, 2011). In this period, the crop behaves as a weak competitor and is highly susceptible to the interference of weeds that limit its development as the result of competition for essential resources, such as water, light and nutrients (Carvalho et al., 2010).

Competition between weeds and crops is one of the most harmful forms of direct interference with agricultural crops, since it results in qualitative and quantitative losses (Vasconcelos et al., 2012). Among resources involved in competition, light gets important in the implementation stage of birdsfoot trefoil because seedlings are extremely susceptible to shading and may be killed by competition. After implementation, competition for water and nutrients gets fiercer, but light is still an essential factor and may interfere with crop development (Ayala and Carámbula, 2009).

Fields that produce forage seeds are usually established in areas where large crops are cultivated. As a result, there is a complex of weeds in these areas, involving monocotyledons and/or dicotyledons, annual and/or perennial ones, whose characteristic is high early growth rate. A study that evaluated the potential of interference of monocotyledonous and dicotyledonous weeds with the production of birdsfoot trefoil seeds showed that the latter led to higher decrease in final crop productivity, by comparison with the former (Formoso et al., 1995).

One of the main objectives a seed producer should have is weed management in production areas. However, it is complex, since forage crops and weeds usually exhibit similarities regarding morphophysiological characteristics, such as dormancy, dispersal and resistance to environmental stress. Besides, the higher the morphophysiological proximity between the forage and the weed, the fiercer the competition for limited resources in a space.
The most common method used for controlling weeds is the chemical one because it is fast, efficient and flexible, besides being inexpensive. It enables effective control in row crops, applicability to large areas, high operational productivity and low need for manpower (Oliveira Jr., 2011). Even though the use of the chemical method is indispensable in birdsfoot trefoil crops, there are no commercial products registered in Brazil to account for weed management, a fact that characterizes it as a crop with insufficient phytosanitary support.

The hypothesis of this study is that post-emergent herbicides registered for soybean, corn and garlic crops do not cause phytotoxicity to birdsfoot trefoil, regardless of their development stages, and provide satisfactory weed control. Therefore, this study aimed at evaluating selectivity of post-emergent herbicides for weed control in birdsfoot trefoil crops.

\section{MATERIAL AND METHOdS}

In order to evaluate selectivity of post-emergent herbicides in birdsfoot trefoil crops, studies were carried out in both vegetative and reproductive development stages in a greenhouse and on a field, in the Weed Science Research Group that belongs to the Agricultural Sciences School at the Universidade Federal de Pelotas, located in Capão do Leão, RS, Brazil.

In the greenhouse, two experiments had a completely randomized design with four replicates. Treatments comprised 11 post-emergent herbicides and the control, which was not submitted to any herbicide (Table 1). Herbicide doses under investigation were based on maximum doses registered for soybean, corn and garlic crops, except glyphosate (Agrofit, 2016). Application was carried out with a $\mathrm{CO}_{2}$-pressurized backpack sprayer fitted with flat fan nozzles (110.015) and calibrated to provide flow rate of $120 \mathrm{~L} \mathrm{ha}^{-1}$.

Experimental units were composed of 8 liter plastic vases filled with $7.0 \mathrm{~kg}$ soil classified into Red-yellow Argissol and sandy-loamy texture (Embrapa, 2009) and the following characteristics: $\mathrm{pH}$ in water $=5.4$; $\mathrm{CTC}_{\mathrm{pH} 7}=5.8 \mathrm{cmol}_{\mathrm{c}} \mathrm{dm}^{-3}$; organic matter $=1.1 \%$; clay $=15 \%$; class $=4 ; \mathrm{Ca}=2.5 \mathrm{cmol}_{\mathrm{c}} \mathrm{dm}^{-3} ; \mathrm{Mg}=0.9 \mathrm{cmol}_{\mathrm{c}}$ $\mathrm{dm}^{-3} ; \mathrm{Al}=0.1 \mathrm{cmol}_{\mathrm{c}} \mathrm{dm}^{-3} ; \mathrm{P}=9.4 \mathrm{mg} \mathrm{dm}^{-3} ;$ and $\mathrm{K}=$ $61 \mathrm{mg} \mathrm{dm}^{-3}$. Four São Gabriel birdsfoot trefoil plants were sown and established in every experimental unit, which was fertilized in agreement with recommendations issued for the crop (CQFS, 2016). 
Table 1 - Post-emergent herbicides used in experiments of selectivity and weed control

\begin{tabular}{|c|c|c|c|}
\hline Mechanism of action & Chemical group & Active ingredient & $\begin{array}{c}\text { Dose } \\
\left.\text { (g i.a./e.a. ha }^{-1}\right)\end{array}$ \\
\hline $\mathrm{ALS}^{(1)}$ inhibitor & Imidazolinone $^{*}$ & Imazethapyr & 100 \\
\hline ALS inhibitor & Imidazolinone* & Imazamox $^{(6)}$ & 49 \\
\hline ALS inhibitor & Sulfonylurea* & Chlorimuron-ethyl ${ }^{(7)}$ & 20 \\
\hline ALS inhibitor & Triazolopyrimidines* & Flumetsulam & 140 \\
\hline ALS inhibitor & Triazolopyrimidines* & Cloransulam-methyl & 40 \\
\hline FS II ${ }^{(2)}$ inhibitor & Benzothiadiazoles* & Bentazon $^{(7)}$ & 720 \\
\hline FS II inhibitor & Benzonitriles ${ }^{\star \star *}$ & loxynil & 500 \\
\hline EPSPs $^{(3)}$ inhibitor & Substituted glycine* & Glyphosate & 534 \\
\hline PROTOX(4) inhibitor & Diphenyl ether* & Fomesafen $^{(6)}$ & 250 \\
\hline PROTOX inhibitor & Triazolinone* & Carfentrazone-ethy $\left.\right|^{(7)}$ & 30 \\
\hline 4-HPPD ${ }^{(5)}$ inhibitor & Tricetones** & Mesotrione & 192 \\
\hline
\end{tabular}

Source: adapted from Agrofit, 2016. (1) Acetolactate synthase; (2) Photosystem II; (3) 5-enolpyruvylshikimate-3-phosphate synthase; ${ }^{(4)}$ Protoporphyrinogen oxidase; ${ }^{(5)} 4$-hydroxyphenylpyruvate-dioxygenase; ${ }^{(6)}$ Addition of surfactant. ${ }^{7}$ Addition of oil adjuvant. Registered for soybean $^{*}$, corn $^{\star *}$ and garlic ${ }^{* * *}$ crops.

In the first experiment, treatments were applied when the crop was in its vegetative stage, after the first cut of the aerial parts of plants, which was carried out by a pair of scissors and a ruler; $10 \mathrm{~cm}$ high residue was left in the plant as a way of simulating uniformization mowing, usually performed in birdsfoot trefoil by seed companies (Ayala and Carámbula, 2009). Conditions throughout application were $70 \%$ relative humidity $(\mathrm{RH})$ and wind speed of $1.0 \mathrm{~m} \mathrm{~s}^{-1}$ at $17^{\circ} \mathrm{C}$. The variable under analysis was phytotoxicity (PHYTO), 10 and 20 days after application (DAA), with the use of a percentage scale that ranges from zero to 100 (zero corresponds to absence of harm and 100 means plant death) (Frans and Crowley, 1986).

In the second experiment, treatments were applied when the crop was in its reproductive stage (25\% of blooming). Two cuts were made in the aerial part of plants throughout crop development. At application, means of $\mathrm{RH}$, temperature and wind speed were $64 \%, 25.0^{\circ} \mathrm{C}$ and $1.2 \mathrm{~m} \mathrm{~s}^{-1}$, respectively.

Variables under analysis were PHYTO, plant height (HEI), shoot dry matter (SDM) and root dry matter (RDM). Regarding PHYTO, evaluations were conducted 10, 20 and 30 DAA with the use of the previously described scale, while HEI was measured by a ruler $30 \mathrm{DAA}$, from the level of the soil to the plant apex, with the distended leaf limbo. Afterwards, in order to evaluate both SDM and RDM, aerial parts on the soil level and the root system were collected after washing soil particles away in running water. All plant material was submitted to a drying process in a forced air oven at $60^{\circ} \mathrm{C}$ for 72 hours. Finally, it was weighed.

In all experiments, resulting data were evaluated in terms of normality (Shapiro-Wilk Test) and homoscedasticity (Hartley's Test) and then submitted to the analysis of variance $(p \leq 0.05)$. When there was statistical significance, means were compared by the Duncan's Test $(p \leq 0.05)$. Concerning the determination of selective post-emergent herbicides, the ones that led to PHYTO equal or below $15 \%$ and did not significantly interfere with morphological variables HEI, SDM and RDM, by comparison with the control, were prioritized.

Herbicides that showed the highest selectivity in the greenhouse were selected to be used in the experiments on the field. Thus, experiments were also carried out in both vegetative and reproductive development stages in a randomized block design with four replicates. Experimental units were composed of $12.5 \mathrm{~m}^{2}(5 \times 2.5 \mathrm{~m})$ plots. Treatments were composed of five herbicides and the control (with no application) (Table 2).

Before sowing, the soil was conventionally prepared with plowing and two harrowing operations - to provide a finer finish - in both experiments. Sowing was carried out by a plot sowing machine for forage, whose working width is $2.5 \mathrm{~m}$ and whose density was regulated to distribute $10 \mathrm{~kg} \mathrm{ha}^{-1}$ of viable seeds by broadcast seeding, with subsequence burial of seed. Basal fertilization was conducted in agreement with recommendations issued by the Handbook of Fertilization and Liming for Rio Grande do Sul and Santa Catarina states, Brazil. Expected yield of dry matter was $4.0 \mathrm{t} \mathrm{ha}^{-1}$ (CQFS, 2016).

In the case of the experiment carried out in the vegetative stage, neither topdressing fertilization nor phytosanitary management, nor drawdown was conducted throughout crop development because of precocious application to the crop 90 days after emergence (DAE). At application, dry matter of forage incident to the area was $800 \mathrm{~kg} \mathrm{ha}^{-1}$ and means of $\mathrm{RH}$, temperature and wind speed were $63 \%, 24.4^{\circ} \mathrm{C}$ and $1.0 \mathrm{~m} \mathrm{~s}^{-1}$, respectively. 
Table 2 - Post-emergent herbicides used in field experiments

\begin{tabular}{|c|c|c|c|}
\hline Mechanism of action & Chemical group & Active ingredient & $\begin{array}{c}\text { Dose } \\
\left.\text { (g i.a. ha }^{-1}\right)\end{array}$ \\
\hline $\mathrm{ALS}^{(1)}$ inhibitor & Imidazolinone & Imazethapyr & 100 \\
\hline ALS inhibitor & Sulfonylurea & Chlorimuron-ethyl( ${ }^{(3)}$ & 20 \\
\hline ALS inhibitor & Triazolopyrimidines & Flumetsulam & 140 \\
\hline ALS inhibitor & Triazolopyrimidines & Cloransulam-methyl & 40 \\
\hline PROTOX ${ }^{(2)}$ inhibitor & Diphenyl ether & Fomesafen $^{(4)}$ & 250 \\
\hline
\end{tabular}

Source: adapted from Agrofit, 2016. ${ }^{(1)}$ Acetolactate synthase; ${ }^{(2)}$ Protoporphyrinogen oxidase; ${ }^{(3)}$ Addition of oil adjuvant; ${ }^{(4)}$ Addition of surfactant.

In the experiment conducted in the reproductive stage, herbicides were applied to manage weeds. Two applications of flumetsulam (140 g i.a. ha $\left.{ }^{-1}\right)$ and one of clethodim (120 g i.a. ha-1), with the addition of an oil adjuvant at $0.5 \% \mathrm{v} / \mathrm{v}$, were made. Besides, during crop development, drawdown was carried out 170 DAE by a motorized mower, which resulted in a $7-10 \mathrm{~cm}$ high residual matter.

Treatments were applied 190 DAE, when the crop exhibited $50 \%$ blooming in the reproductive stage. Dry matter of the forage incident to the area at application was $4,000 \mathrm{~kg} \mathrm{ha}^{-1}$ and means of $\mathrm{RH}$, temperature and wind speed were $68 \%, 24.0^{\circ} \mathrm{C}$ and $1.1 \mathrm{~m} \mathrm{~s}^{-1}$, respectively.

Phytotoxicity (PHYTO) was evaluated 10, 20 and 30 DAA by a similar scale to the previously described one. SDM was also evaluated 30 DAA by collecting the aerial part on the soil level in an area of $0.25 \mathrm{~m}^{2}$ in every experimental unit. It was dried in a forced air oven at $60^{\circ} \mathrm{C}$ for 72 hours and weighed.

In all experiments, data were evaluated in terms of normality (Shapiro-Wilk Test) and homoscedasticity (Hartley's Test) and then submitted to the analysis of variance $(p \leq 0.05)$. When there was statistical significance, means were compared by the Duncan's Test $(p \leq 0.05)$.

\section{RESULTS AND Discussion}

Results of homoscedasticity and normality tests showed that data transformation was not needed for greenhouse and field experiments in any development stage. In the experiment carried out in the vegetative stage in the greenhouse, phytotoxic effect of all herbicides was observed 10 and 20 DAA (Table 3).

In the evaluation that took place 10 DAA, both ALS inhibiting herbicides imazamox and flumetsulam were the only ones that were selective to the crop; they did not differ from the control (Table 3). The evaluation that happened 20 DAA showed decrease from $4.0 \%$ to $6.0 \%$ in phytotoxicity of plants submitted to herbicides chlorimuron-ethyl, cloransulam-methyl, ioxynil and fomesafen. The other treatments exhibited increase in PHYTO, mainly in plants treated with herbicides bentazon and mesotrione. This evaluation also highlighted herbicides flumetsulam, cloransulam-methyl and imazamox as being selective to the crop.

Table 3 - Phytotoxicity (PHYTO) (\%) caused to birdsfoot trefoil crops in the vegetative stage 10 and 20 days after application (DAA) of treatments

\begin{tabular}{lcc}
\hline \multirow{2}{*}{ Herbicide } & \multicolumn{2}{c}{ Phytotoxicity(\%) } \\
\cline { 2 - 3 } & $10 \mathrm{DAA}^{(1)}$ & $20 \mathrm{DAA}$ \\
\hline Control & $0.0 \mathrm{~g}$ & $0.0 \mathrm{~h}$ \\
Imazethapyr & $12.5 \mathrm{de}$ & $15.3 \mathrm{e}$ \\
Imazamox & $3.3 \mathrm{~g}$ & $6.7 \mathrm{fg}$ \\
Chlorimuron-ethyl & $19.8 \mathrm{c}$ & $15.3 \mathrm{e}$ \\
Flumetsulam & $5.0 \mathrm{fg}$ & $5.5 \mathrm{fgh}$ \\
Cloransulam-methyl & $9.5 \mathrm{ef}$ & $4.0 \mathrm{gh}$ \\
Bentazon & $21.8 \mathrm{c}$ & $41.5 \mathrm{c}$ \\
loxynil & $16.0 \mathrm{~cd}$ & $10.0 \mathrm{efg}$ \\
Glyphosate & $93.3 \mathrm{a}$ & $98.7 \mathrm{a}$ \\
Fomesafen & $16.3 \mathrm{~cd}$ & $11.3 \mathrm{ef}$ \\
Carfentrazone-ethyl & $68.3 \mathrm{~b}$ & $71.0 \mathrm{~b}$ \\
Mesotrione & $18.8 \mathrm{C}$ & $33.3 \mathrm{~d}$ \\
\hline CV (\%) & 14.9 & 15.8 \\
\hline
\end{tabular}

(1) Days after application. Means with equal letters in the column do not differ by the Duncan's Test at $5 \%$ probability.

High PHYTO of herbicides glyphosate, carfentrazone-ethyl and bentazon in birdsfoot trefoil plants characterizes treatments with low selectivity potential (Table 3). The typical phytotoxic effect of glyphosate, even at $540 \mathrm{~g} \mathrm{e.a.} \mathrm{ha-1,} \mathrm{was} \mathrm{evident}$ after plant death. Regarding both herbicides carfentrazone-ethyl and bentazon, there was increase in PHYTO and plants did not show any signs of recovery from these effects.

Unlike results found in the vegetative stage, birdsfoot trefoil plants were more tolerant to phytotoxic effects of herbicides imazethapyr, chlorimuron-ethyl, cloransulam-methyl and fomesafen in the reproductive stage (Table 4). Concerning the other herbicides, PHYTO was similar to the one found in the vegetative stage. 
Table 4 - Phytotoxicity (PHYTO) (\%) caused to birdsfoot trefoil crops in the reproductive stage 10,20 and 30 days after application (DAA) of treatments

\begin{tabular}{lccc}
\hline \multirow{2}{*}{ Herbicide } & \multicolumn{3}{c}{ Phytotoxicity (\%) } \\
\cline { 2 - 4 } & $10 \mathrm{DAA}^{(1)}$ & $20 \mathrm{DAA}$ & $30 \mathrm{DAA}$ \\
\hline Control & $0.0 \mathrm{e}$ & $0.0 \mathrm{e}$ & $0.0 \mathrm{e}$ \\
Imazethapyr & $0.0 \mathrm{e}$ & $0.0 \mathrm{e}$ & $0.0 \mathrm{e}$ \\
Imazamox & $0.0 \mathrm{e}$ & $0.0 \mathrm{e}$ & $0.0 \mathrm{e}$ \\
Chlorimuron-ethyl & $0.0 \mathrm{e}$ & $0.0 \mathrm{e}$ & $0.0 \mathrm{e}$ \\
Flumetsulam & $0.0 \mathrm{e}$ & $0.0 \mathrm{e}$ & $0.0 \mathrm{e}$ \\
Cloransulam-methyl & $0.0 \mathrm{e}$ & $1.0 \mathrm{e}$ & $0.0 \mathrm{e}$ \\
Bentazon & $34.0 \mathrm{a}$ & $95.0 \mathrm{a}$ & $98.0 \mathrm{a}$ \\
loxynil & $21.0 \mathrm{c}$ & $11.0 \mathrm{~d}$ & $6.3 \mathrm{~d}$ \\
Glyphosate & $32.3 \mathrm{a}$ & $28.0 \mathrm{~b}$ & $12.3 \mathrm{c}$ \\
Fomesafen & $1.3 \mathrm{e}$ & $12.5 \mathrm{~cd}$ & $15.0 \mathrm{c}$ \\
Carfentrazone-ethyl & $27.5 \mathrm{~b}$ & $15.5 \mathrm{c}$ & $22.3 \mathrm{~b}$ \\
Mesotrione & $10.5 \mathrm{~d}$ & $15.3 \mathrm{c}$ & $14.3 \mathrm{c}$ \\
\hline CV (\%) & 23.2 & 16.2 & 16.6 \\
\hline
\end{tabular}

${ }^{(1)}$ Days after application of treatments. Means with equal letters in the column do not differ by the Duncan's Test at $5 \%$ probability.

The evaluation carried out 10 DAA showed that ALS inhibiting herbicides imazethapyr, imazamox, chlorimuron-ethyl, cloransulam-methyl and flumetsulam caused no PHYTO to birdsfoot trefoil plants (Table 4). On the other hand, herbicides bentazon, glyphosate, carfentrazone-ethyl and ioxynil led to PHYTO above $20 \%$, which is higher than the maximum level of phytotoxicity accepted by regulatory authorities. Plants treated with ALS inhibiting herbicides persisted with no phytotoxic effect 20 and 30 DAA. Birdsfoot trefoil plants recovered from PHYTO caused by herbicides glyphosate and ioxynil and exhibited values below the established ones. However, plants treated with carfentrazone-ethyl, fomesafen and, mainly, bentazon, showed increase in phytotoxicity.

Species, such as soybean, that belong to the family of birdsfoot trefoil also exhibit selectivity of herbicides flumetsulam and chlorimuron-ethyl to the crop and low phytotoxicity 15 DAE (Osipe et al., 2014). In addition, similar phytotoxicity was caused by herbicides imazethapyr, chlorimuron-ethyl and imazamox (Silva et al., 2004) and imazethapyr (Hijano et al., 2013) to alfalfa crops.

Negative effects of the herbicide glyphosate on birdsfoot trefoil plants found by this study are explained by the fact that it is neither selective nor has any systemic activity, whose control spectrum reaches annual and/or perennial monocotyledonous and/or dicotyledonous weeds (Christoffoleti and López-Ovejero, 2003). However, plant recovery from phytotoxic effects of glyphosate highlights the need for further studies of crop behavior, since death of birdsfoot trefoil plants was not observed.
Concerning height (HEI), treatments with herbicides did not differ from the control, except bentazon, glyphosate and mesotrione, which decreased the variable in $21.4 \%, 17.7 \%$ and $18.7 \%$, respectively. Regarding the other treatments, even though neither flumetsulam nor ioxynil differed from the control, they increased plant height in $8.0 \%$ and $6.4 \%$, respectively (Table 5 ).

Table 5 - Height (HEI) (cm per plant), shoot dry matter (SDM) (g) and root dry matter (RDM) (g) of birdsfoot trefoil crops in the reproductive stage 30 days after application (DAA) of treatments

\begin{tabular}{lccc}
\hline Herbicide & $\begin{array}{c}\text { HEl } \\
\text { (cm per plant) }\end{array}$ & SDM (g) & RDM (g) \\
\hline Control & $32.6 \mathrm{abc}$ & $11.7 \mathrm{ab}$ & $36.0 \mathrm{abc}$ \\
Imazethapyr & $28.8 \mathrm{cdef}$ & $13.1 \mathrm{ab}$ & $37.7 \mathrm{ab}$ \\
Imazamox & $30.9 \mathrm{bc}$ & $14.4 \mathrm{a}$ & $35.2 \mathrm{abc}$ \\
Chlorimuron-ethyl & $32.1 \mathrm{abc}$ & $13.3 \mathrm{ab}$ & $33.8 \mathrm{abc}$ \\
Flumetsulam & $35.2 \mathrm{a}$ & $14.3 \mathrm{a}$ & $36.6 \mathrm{abc}$ \\
Cloransulam-methyl & $30.7 \mathrm{~cd}$ & $12.0 \mathrm{ab}$ & $35.9 \mathrm{abc}$ \\
Bentazon & $25.6 \mathrm{f}$ & $3.9 \mathrm{c}$ & $2.9 \mathrm{~d}$ \\
loxynil & $34.7 \mathrm{ab}$ & $11.8 \mathrm{ab}$ & $22.1 \mathrm{c}$ \\
Glyphosate & $26.8 \mathrm{def}$ & $10.8 \mathrm{~b}$ & $22.9 \mathrm{bc}$ \\
Fomesafen & $30.1 \mathrm{cde}$ & $11.0 \mathrm{ab}$ & $42.2 \mathrm{a}$ \\
Carfentrazone-ethyl & $31.9 \mathrm{abc}$ & $11.8 \mathrm{ab}$ & $28.9 \mathrm{abc}$ \\
Mesotrione & $26.5 \mathrm{ef}$ & $11.0 \mathrm{ab}$ & $22.4 \mathrm{bc}$ \\
\hline CV $(\%)$ & 7.0 & 17.6 & 26.3 \\
\hline
\end{tabular}

Means with equal letters in the column do not differ by the Duncan's Test at $5 \%$ probability.

Concerning both variables SDM and RDM, there was no difference between plants exposed to the treatments and the ones that belonged to the control, except in the case of bentazon (Table 5). SDM and RDM values of plants exposed to such herbicide were $66.4 \%$ and $92 \%$ lower than the ones of the control, respectively. Even though neither imazamox nor flumetsulam differed from the control, SDM increased $23.2 \%$ and $22.8 \%$, respectively. Fomesafen also increased RDM, since its value was $16.9 \%$ higher than the one of the control. Increase in HEI and crop biomass ensures better establishment and competitive skills with weeds for environmental resources (Zandoná et al., 2018).

Studies of different crops corroborate data on $\mathrm{HEI}$, SDM and RDM found for ALS inhibiting herbicides by this study. In soybean crops, no negative effect of flumetsulam and chlorimuron-ethyl application was found on plant height (Osipe et al., 2014). Similar responses were observed when imazethapyr and chlorimuron-ethyl were applied to alfalfa crops (Silva et al., 2001; Silva et al., 2003; Hijano et al., 2013).

Different results found in distinct application periods are related to crop development stages. Herbicide application in precocious development 
stages of plants may result in low tolerance to the herbicides. It is corroborated by the fact that applications in different development stages of plants influence tolerance capacity of cowpea (Mancuso et al., 2016), alfalfa (Ricci et al., 2011) and white clover (Machado et al., 2013) crops. In the case of young plants, exposure of growth spots, associated with intense metabolic activity of meristematic tissues, favors increase in herbicide activity, which may lead to phytotoxic effects (Oliveira Jr. and Inoue, 2011).

Selectivity occurs in different ways, since it is the combination of factors related to crops (species), herbicides and the environment (Song et al., 2007). Even if the species is tolerant to a certain active ingredient, physiological and biochemical alterations may happen as secondary effects of herbicides and lead to biochemical and physiological disorders in plant metabolism (Song et al., 2007).

Low temperatures that occurred throughout the experiments may also have influenced crop tolerance to herbicides. Despite the capacity birdsfoot trefoil plants have to survive in the cold, low temperatures may affect their enzyme activity and biochemical and physiological metabolism directly. As a result, their detoxification capacity may be affected and herbicides may cause damage.

Based on parameters of phytotoxicity and on variables $\mathrm{HEI}$, SDM and RDM in both experiments carried out in the greenhouse, herbicides that may be applied to birdsfoot trefoil crops in post-emergence are imazethapyr, imazamox, chlorimuron-ethyl, flumetsulam, cloransulam-methyl, ioxynil and fomesafen, since they do not affect crop development. However, since bentazon, glyphosate, carfentrazone-ethyl and mesotrione caused damage whose values were higher that the established ones, their use is not recommended in crop postemergence.

In the experiments carried out on the field, the analysis of variance showed the effect of treatments with herbicides on PHYTO and SDM in experiments conducted in both vegetative and reproductive stages. In the former, imazethapyr and flumetsulam were selective to birdsfoot trefoil plants $10 \mathrm{DAA}$ and there was difference in phytotoxicity by comparison with the control (Table 6). Plants were more sensitive to chlorimuron-ethyl and cloransulam-methyl; damage was characterized by leaf chlorosis and PHYTO was $10 \%$ and $17 \%$, respectively. However, fomesafen let to $50 \%$ PHYTO 10 DAA, a fact that highlights the low selectivity of the herbicide to plants when it is applied throughout the establishment stage. Damage caused by fomesafen was characterized by intense leaf necrosis (where the herbicide was deposited) and decrease in plant height.

All herbicides exhibited decrease in phytotoxicity 20 and 30 DAA (Table 6). Best results were provided by ALS inhibiting herbicides imazethapyr, chlorimuron-ethyl and flumetsulam $30 \mathrm{DAA}$. It confirms their selectivity to birdsfoot trefoil crops. Regarding cloransulam-methyl, PHYTO decreased as the result of the emission of new twigs, but, even so, they exhibited leaf chlorosis. In the case of fomesafen, emission of new leaves and twigs resulted in decrease in phytotoxicity 30 DAA, but this recovery does not qualify the herbicide as selective to the crop.

Table 6 - Phytotoxicity (PHYTO) (\%) caused to birdsfoot trefoil crops in the vegetative stage 10,20 and 30 days after application (DAA) of treatments on the field

\begin{tabular}{lccc}
\hline \multirow{2}{*}{ Herbicide } & \multicolumn{3}{c}{ Phytotoxicity (\%) } \\
\cline { 2 - 4 } & $10 \mathrm{DAA}^{(1)}$ & $20 \mathrm{DAA}$ & $30 \mathrm{DAA}$ \\
\hline Control & $0.0 \mathrm{~d}$ & $0.0 \mathrm{~d}$ & $0.0 \mathrm{c}$ \\
Imazethapyr & $4.0 \mathrm{~d}$ & $1.0 \mathrm{~d}$ & $0.0 \mathrm{c}$ \\
Chlorimuron-ethyl & $9.5 \mathrm{c}$ & $5.0 \mathrm{c}$ & $0.0 \mathrm{c}$ \\
Flumetsulam & $3.6 \mathrm{~d}$ & $1.8 \mathrm{~d}$ & $0.0 \mathrm{c}$ \\
Cloransulam-methyl & $16.7 \mathrm{~b}$ & $14.8 \mathrm{~b}$ & $4.5 \mathrm{~b}$ \\
Fomesafen & $50.0 \mathrm{a}$ & $47.7 \mathrm{a}$ & $26.0 \mathrm{a}$ \\
\hline CV (\%) & 22.3 & 15.5 & 23.6 \\
\hline
\end{tabular}

(1) Days after application of treatments. Means with equal letters in the column do not differ by the Duncan's Test at $5 \%$ probability.

Results of SDM corroborate the ones of phytotoxicity, since values found for treatments with herbicides were lower than the ones of the control, except in the cases of imazethapyr and flumetsulam, whose values did not differ from the ones of the control. Chlorimuron-ethyl led to decrease in $21 \%$ of SDM, by comparison with the control, but it did not differ from imazethapyr and flumetsulam. Both cloransulam-methyl and fomesafen led to the lowest SDM accumulation; thus, they are the most harmful treatments to birdsfoot trefoil crops.

Concerning fomesafen, decrease in about $50 \%$ in SDM accumulation, by comparison with the control, may be explained by the intensity of damage previously described in phytotoxicity (Table 6). Regarding cloransulam-methyl, decrease in $40 \%$ in SDM did not match plant recovery from phytotoxic symptoms, a fact that points out invisible and/or hidden phytotoxicity. However, SDM values found for cloransulam-methyl corroborate the ones found in the 
reproductive stage. Values found for fomesafen disagree with them as the result of high PHYTO.

In the experiment that was carried out in the reproductive stage, cloransulam-methyl led to the highest phytotoxic effects on the crop 10, 20 and 30 DAA (Table 7); damage was characterized by decrease in growth, associated with leaf chlorosis in the crop. Imazethapyr, chlorimuron-ethyl, flumetsulam and fomesafen only caused PHYTO to the crop 10 DAA. It was below $5 \%$ and symptoms were typical of leaf chlorosis.

Table 7 - Phytotoxicity (PHYTO) (\%) caused to birdsfoot trefoil crops in the reproductive stage 10,20 and 30 days after application (DAA) of treatments on the field

\begin{tabular}{lccc}
\hline \multirow{2}{*}{ Herbicide } & \multicolumn{3}{c}{ Phytotoxicity(\%) } \\
\cline { 2 - 4 } & $10 \mathrm{DAA}^{(1)}$ & $20 \mathrm{DAA}$ & $30 \mathrm{DAA}$ \\
\hline Control & $0.0 \mathrm{c}$ & $0.0 \mathrm{~b}$ & $0.0 \mathrm{~b}$ \\
Imazethapyr & $4.0 \mathrm{~b}$ & $0.0 \mathrm{~b}$ & $0.0 \mathrm{~b}$ \\
Chlorimuron-ethyl & $3.3 \mathrm{~b}$ & $0.0 \mathrm{~b}$ & $0.0 \mathrm{~b}$ \\
Flumetsulam & $2.3 \mathrm{bc}$ & $0.0 \mathrm{~b}$ & $0.0 \mathrm{~b}$ \\
Cloransulam-methyl & $10.0 \mathrm{a}$ & $13.0 \mathrm{a}$ & $14.5 \mathrm{a}$ \\
Fomesafen & $3.0 \mathrm{~b}$ & $0.0 \mathrm{~b}$ & $0.0 \mathrm{~b}$ \\
\hline $\mathrm{CV}(\%)$ & 39.1 & 35.0 & 13.4 \\
\hline
\end{tabular}

(1) Days after application. Means with equal letters in the column do not differ by the Duncan's Test at $5 \%$ probability.

Evaluations conducted 20 and 30 DDA showed the capacity of recovery that birdsfoot trefoil plants have when treated with imazethapyr, chlorimuron-ethyl, flumetsulam and fomesafen, since no symptoms of phytotoxicity were observed in these periods (Table 7). Even though imazethapyr, chlorimuronethyl and flumetsulam belong to different chemical groups, they caused similar phytotoxicity to birdsfoot trefoil plants. Despite being chemically different, imidazolinones, sulfonylureas and triazolopyrimidines act in the same site and usually trigger similar phytotoxicity symptoms in plants (Oliveira Jr., 2011). Similar damage was caused by imazethapyr and chlorimuron-ethyl to Stylosanthes capitata and S. macrocephala plants (Verzignassi et al., 2005). On the other hand, alfalfa (Silva et al., 2003) and white clover (Machado et al., 2013) crops exhibited damage caused by chlorimuron-ethyl, but it was not caused by imazethapyr.

Regarding fomesafen, resulting PHYTO and subsequent recovery corroborated the experiment carried out in the reproductive stage (in the greenhouse), but disagrees with data found in the vegetative stage. It provides evidence of the fact that plant development stages are directly connected to their sensitivity to certain herbicides. Similar selectivity was found in cowpea crops (Mancuso et al., 2016), implying that the stage in which it is applied influences tolerance to fomesafen. Late applications mitigate the probability of occurring damage, since plants at early development stages are more sensitive to herbicides, by comparison with more developed plants (Gilreath et al., 2000).

Concerning SDM, there was increase in $26 \%$ in plants treated with imazethapyr, by comparison with the ones that were not treated (Table 8). However, there was decrease in $36 \%$ in the accumulation of the variable in plants submitted to cloransulam-methyl application. In the case of plants exposed to chlorimuron-ethyl and flumetsulam application, there was also decrease in the accumulation of dry matter, by comparison with the control. Values of these herbicides were $10.8 \%$ and $21.1 \%$ lower than the ones of the control, respectively. This response must be taken into consideration when herbicides are selected because decrease in biomass accumulation may affect quantity and quality of seeds produced by plants, due to low production of photoassimilates.

Table 8 - Shoot dry matter (SDM) (g) of birdsfoot trefoil crops in both vegetative and reproductive stages 30 days after application (DAA) of treatments on the field

\begin{tabular}{lcc}
\hline \multirow{2}{*}{ Herbicide } & $\begin{array}{c}\text { Vegetative } \\
\text { stage }\end{array}$ & $\begin{array}{c}\text { Reproductive } \\
\text { stage }\end{array}$ \\
\cline { 2 - 3 } & \multicolumn{2}{c}{ SDM (g) } \\
\hline Control & $92.6 \mathrm{a}$ & $82.4 \mathrm{~b}$ \\
Imazethapyr & $77.6 \mathrm{ab}$ & $104.2 \mathrm{a}$ \\
Chlorimuron-ethyl & $72.4 \mathrm{bc}$ & $73.4 \mathrm{c}$ \\
Flumetsulam & $83.5 \mathrm{ab}$ & $67.9 \mathrm{c}$ \\
Cloransulam-methyl & $56.0 \mathrm{~cd}$ & $52.5 \mathrm{~d}$ \\
Fomesafen & $47.0 \mathrm{~d}$ & $94.4 \mathrm{ab}$ \\
\hline CV $\%$ ) & 13.6 & 8.2 \\
\hline
\end{tabular}

Means with equal letters in the column do not differ by the Duncan's Test at $5 \%$ probability.

The compensatory response of the crop to chemical stress observed for imazethapyr may be attributed to the effect of hormosis. Studies have shown the effect of hormosis on L. corniculatus biomass when exposed to low concentrations of herbicides that inhibit the enzyme glutamine synthetase (GS) (Dragićević et al., 2013).

Selectivity of ALS inhibiting herbicides to birdsfoot trefoil crop may be associated with metabolization or decrease in absorption and translocation. Selectivity characterized by metabolization of herbicides into non-toxic metabolites is usually associated with herbicides that belong to the chemical group of imidazolinones and sulfonylureas (Vidal and Merotto Jr., 2001; Oliveira Jr., 2011), while selectivity based 
on the speed of absorption and translocation and metabolism rate in plants is a characteristic of herbicides that belong to the chemical group of triazolopyrimidines (Vidal and Merotto Jr., 2001). Thus, in the case of imazethapyr, it occurs mainly by metabolization of molecules into inactive compounds, while in the case of flumetsulam, it depends on absorption time, translocation and speed of metabolization (Leite et al., 1998; Vidal and Merotto Jr., 2001).

Results of fomesafen were corroborated by studies of alfalfa (Hijano et al., 2013), white clover (Machado et al., 2013), crambe (Souza et al., 2014) and cowpea (Burgos et al., 2007; Fontes et al., 2013) crops, which showed that herbicide application led to high phytotoxicity after application and also interfered with shoot dry matter and productivity. Since fomesafen is a plasma membrane deregulator, its contact with plants leads to fast tissue necrosis. Damage takes place soon after application and becomes visible from one to two days (Lee et al., 1993).

Results found in every experiment are valid for the birdsfoot trefoil cultivar in the previously described environment and type of soil. Thus, new studies of selectivity of herbicides to other cultivars, in different environments and types of soil, are needed, since these factors may influence tolerance levels of plants to herbicides, besides their availability to crops. New results may be highly applicable to register herbicides for birdsfoot trefoil crops and become an essential tool to solve problems related to their slow establishment.

\section{CONCLUSIONS}

Herbicides imazethapyr, chlorimuron-ethyl and flumetsulam, when applied in post-emergence, regardless of the development stage, are selective to birdsfoot trefoil crops and do not affect crop development, while both cloransulam-methyl and fomesafen are not selective to them.

\section{CONTRIBUTIONS}

This work was carried out in collaboration with all authors. The author BMS: managed and planned the study, wrote the manuscript, carried out bibliographical research. The author DA: planned the study, wrote the manuscript and performed the analysis of the study. The author RRZ: planned the study, wrote the manuscript and carried out the analysis of the study. The author RCAN: Carried out the analyzes of the study and wrote the manuscript. The author JT: carried out the analyzes of the study.

\section{ACKNOWLEDGEMENTS}

This study was financed in part by the Coordenação de Aperfeiçoamento de Pessoal de Nível Superior Brasil (CAPES) - Finance Code 001. The authors would like to thank Conselho Nacional de Desenvolvimento Científico e Tecnológico (CNPq) for the scholarship and financial support. To CNPq for the Research Fellowship of Dr. Dirceu Agostinetto/ N.Proc. 308363/2018-3 CNPq.

\section{REFERENCES}

Agrofit. Sistema de agrotóxicos fitossanitários [accessed on 25 Oct 2016]. Available at:

http://extranet.agricultura.gov.br/agrofit_cons/principal_agr ofit_cons.

Ayala W, Carámbula M. El valor agronómico del gênero Lotus. Uruguai: INIA; 2009. 424p.

Burgos NR, Brandenberger LP, Stiers EN, Shivrain VK, Motes DR, Wells L, et al. Tolerance of selected advanced cowpea (Vigna unguiculata) breeding lines to fomesafen. Weed Tech. 2007;21:863-8.

Carvalho PCF, Santos DT, Gonçalves EM, Moraes A, Nabinger C. Forrageiras de clima temperado. In: Fonseca DM, Martuscello JA. Plantas For. 2010;1:494-537.

Christoffoleti, PJ, López-Ovejero R. Principais aspectos da resistência de plantas daninhas ao herbicida glyphosate. Planta Daninha. 2003;21:507-15.

CQFS-RS/SC - Comissão de Química e Fertilidade do Solo. Manual de calagem e adubação para os estados do Rio Grande do Sul e Santa Catarina. 11. ed. Santa Maria: Sociedade Brasileira de Ciência do Solo; 2016. 376p.

Dragićević M, Platiša J, Nikolić R, Todorović $\mathrm{S}$, Bogdanović M, Mitić N, et al. Herbicide phosphinothricin causes direct stimulation hormesis. Dose-Resp. 2013;11:344-60.

Embrapa. Centro Nacional de Pesquisa de Solos. Sistema brasileiro de classificação de solos. 2.ed. Rio de Janeiro: Embrapa Solos; 2009. 412p.

Fontes JRA, Oliveira IJ, Gonçalves JRP. Seletividade e eficácia de herbicidas para cultura do feijão-caupi. Rev Bras Herb. 2013;12:47-55.

Formoso F. Producción de semillas de especies forrajeras. Uruguai: INIA; 2011. 234p.

Formoso R, Saraiva I, Rios A. Lotus subbiflorus: efecto de la interferencia de malezas mono y dicotiledoneas. In: Anais do 12. Congresso Latinoamericano de Malezas, 12, 1995, Uruguai. Uruguai: INIA; 1995. p.240-6.

Frans $\mathrm{R}$, Crowley $\mathrm{H}$. Experimental design and techniques for measuring and analyzing plant responses to weed control practices. Res Meth Weed Sci. 1986;3:29-45.

Grant WF, Small E. The origin of the Lotus corniculatus (Fabaceae) complex: a synthesis of diverse evidence. Canadian J Bot. 1996;74:975-98. 
Gilreath JP, Chase CA, Locascio SJ. Phytotoxic effects of glyphosate on pepper (Capsicum annuum). Weed Tech. 2000;14:488-94.

Hijano N, Monquero PA, Munhoz WS, Gusmão MR. Herbicide selectivity in alfalfa crops. Planta Daninha. 2013;31:903-18.

Leite CRF, Almeida JCV, Prete CEC. Aspectos fisiológicos, bioquímicos e agronômicos dos herbicidas inibidores da enzima ALS (AHAS). Londrina-PR; 1998. $68 p$.

Lee HJ, Duke MV, Duke SO. Cellular localization of protoporphyrinogenxidizing activities of etiolated barley (Hordeum vulgare L.) leaves (relationship to mechanism of action of protoporphyrinogen oxidase inhibiting herbicides). Plant Phys. 1993;102:881-9.

Machado D, Lustosa SBC, Baldissera TC, Turok JDN, Machado M, Watzlawick LF, et al. Seletividade de herbicidas em trevo-branco no estádio fenológico de expansão do primeiro trifólio. Ci Rural. 2013;43:2132-8.

Mancuso MAC, Aires BC, Negrisoli E, Corrêa MR, Soratto RP. Seletividade e eficiência de herbicidas no controle de plantas daninhas na cultura do feijão-caupi. Rev Ceres. 2016;63:25-32.

Oliveira Jr RS. Introdução ao controle químico. In: Oliveira Jr RS, Consttantin J, Inoue MH. Biologia e manejo de plantas daninhas. Curitiba, PR: Omnipax; 2011. p.125-39.

Oliveira Jr RS, Inoue MH. Seletividade de herbicidas para culturas e plantas daninhas. In: Oliveira Jr RS, Consttantin $\mathrm{J}$, Inoue MH. Biologia e manejo de plantas daninhas. Curitiba, PR: Omnipax; 2011. p.243-62.

Osipe JB, Oliveira Jr. RS, Constantin J, Biffe DF, Rios FA, Franchini LHM, et al. Seletividade de aplicações combinadas de herbicidas em pré e pós-emergência para a soja tolerante ao glyphosate. Biosc J. 2014;30:623-31.

Ricci TT, Piccinin GG, Dan LGM, Barroso ALL, Carrijo MS, Ortiz AHT. Avaliação de seletividade dos herbicidas chlorimuron-ethyl e nicosulfuron aplicados em pósemergência na cultura da alfafa. Rev Bras Herb. 2011;10:20-8.

Silva W, Vilela D, Ferreira LR, Ferreira RP, Ferreira FA. Tolerância da alfafa (Medicago sativa L.) a diferentes herbicidas aplicados em pré-emergência e pósemergência. Rev Ceres. 2001;48:415-25.

Silva W, Vilela D, Pereira AV, Ferreira RP, Cobucci T. Eficiência de herbicidas na cultura da alfafa em fase de estabelecimento. Rev Ceres. 2003;50:171-81.

Silva, W, Vilela D, Cobucci T, Heinemann AB, Reis FA, Pereira AV, et al. Avaliação da eficiência de herbicidas no controle de plantas daninhas em alfafa. Ciênc Agrot. 2004;28:729-35.

Song NH, Yin XL, Chen GF, Yang H. Biological responses of wheat (Triticum aestivum) plants to the herbicide chlorotoluron in soils. Chemosphere. 2007;68:1779-87.

Souza GSF, Vitorino HS, Fioreze ACCL, Pereira MRR; Martins D. Seletividade de herbicidas na cultura de crambe. Semina Ciên Agr. 2014; 35:161-168.

Vidal RA, Merotto Jr. A. Herbicidas inibidores de ALS. In: Vidal RA, Merotto Jr A. Herbicidologia. Porto Alegre: [s.n.]; 2001. p.15-24.
Vasconcelos MCC, Silva AFA, Lima RS. Interferência de plantas daninhas sobre plantas cultivadas. Agropec Ciênc Sem. 2012;8:1-6.

Verzignassi J, Pereira FAR, Fernandes CD, Vida JB.

Seletividade de herbicidas a Stylosanthes capitata e a S. macrocephala. Rev Bras Herb. 2005;4:59-67.

Zandoná RR, Agostinetto D, Silva BM, Ruchel Q, Fraga DS. Interference periods in soybean crop as affected by emergence times of weeds. Planta Daninha. 2018;36:111. 